\title{
Interactions between marine bacteria and axenic diatoms (Cylindrotheca fusiformis, Nitzschia laevis, and Thalassiosira weissflogii) incubated under various conditions in the lab
}

\author{
Hans-Peter Grossart* \\ Scripps Institution of Oceanography, University of California, San Diego, 9500 Gilman Dr., La Jolla, California 92093-0202, USA
}

\begin{abstract}
Bacteria-phytoplankton interactions in aquatic systems range from symbiosis to parasitism and are highly variable in space and time. Three marine diatoms (Cylindrotheca fusiformis, Nitzschia laevis, and Thalassiosira weissflogil) were grown in axenic culture and incubated under controlled lab conditions with single bacterial isolates, mixed bacterial populations, and seawater off Scripps Pier. Growth of both bacteria and algae was significantly higher when incubated together in $f / 2$ medium or artificial seawater which were rich in inorganic nutrients, vitamins, and trace metals. In contrast, growth of diatoms in a vitamin and trace metal free medium was reduced or even negative when incubated together with bacterial isolates or seawater bacteria. In addition, the amount and quality of

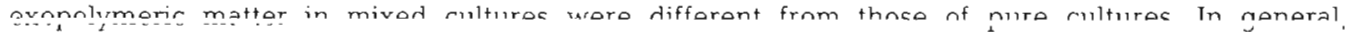
aminopeptidase and $\beta$-glucosidase activities of bacteria in mixed cultures strongly increased after $70 \mathrm{~h}$ whereas those of a pure culture (Fl 7) were slightly higher until 50 to $70 \mathrm{~h}$ of incubation but strongly decreased thereafter. High growth and enhanced hydrolytic ectoenzyme activities of bacteria in the presence of algae and polymer particles led to high bacterial remineralization of organic nutrients increasing phytoplankton growth. However, bacteria compete with phytoplankton for nutrients and can inhibit algal growth under certain environmental conditions. Thus, changes in eutrophication and pollution can alter bacteria-phytoplankton interactions, which influence the flux and cycling of nutrients and carbon at both micro- and global scale.
\end{abstract}

KEY WORDS: Bacteria · Diatoms - Exopolymers · Bacterial colonization · Carbon cycle

\section{INTRODUCTION}

Bacteria can be loosely or tightly associated with phytoplankton (ZoBell 1941, Sieburth 1968, Caldwell 1977), leading to a multitude of possible interactions between these organisms in aquatic environments (see review Cole 1982). Algal blooms create 'phycospheres' in which microbial activity is altered from that of the surrounding milieu (Bell \& Mitchell 1972). Bacteria in

- Present address: Institute for Chemistry and Biology of the Marine Environment, University of Oldenburg, PO Box 2503, D-26111 Oldenburg, Germany.

E-mail: hgrossart@icbm.uni-oldenburg.de phycospheres can be free-living, directly attached to phytoplankton surfaces, or live inside phytoplankton cells (Kochert \& Olson 1970, Kodama et al. 1990, Rausch de Traubenberg \& Lassus 1991).

The following bacteria-phytoplankton interactions, predominatly studied in laboratory experiments, were identified: (1) Bacteria and algae form symbioses in which bacteria benefit from phytoplankton products such as exudates (Bell et al. 1974, Cole 1982) whereas phytoplankton profits of bacterial products such as remineralized nutrients (Golterman 1972), vitamins (Pringsheim 1912, Haines \& Guillard 1974), and other growth factors (Paerl \& Pinckney 1996). (2) Bacteria are parasites of phytoplankton which penetrate and become lodged in the periplasmatic space of the host cell 
and may lead to cell lysis and death (see review Cole 1982, Imai et al. 1993). To prevent bacterial parasitism many algae have the capability to produce antibiotics (Steeman-Nielsen 1955, Sieburth 1968, Sastry \& Rao 1994). (3) Commensalic bacteria benefit from phytoplankton without having any negative effect on it (Barbeyron \& Berger 1989). However, the distinction between commensalism and parasitism is transient and bacterial commensalism may result in parasitism when the phytoplankton becomes stressed. (4) Bacteria are loosely associated with phytoplankton and can compete for limited nutrients such as phosphate (Rhee 1972, Rothhaupt \& Güde 1992). In natural environments including heterogeneous communities of bacteria and phytoplankton multiple interactions and relations exist simultaneously which can be highly variable in time and space.

Specific bacteria-phytoplankton interactions such as the clustering of chemotactic bacteria in the vicinity of phytoplankton cells lead to patchy distributed bacterial communities and activities (Blackburn et al. 1997. Grossart in press). Most pelagic bacteria have a repertoire of hydrolytic enzymes which allows them to efficiently utilize polymeric organic material such as phytoplankton exudates (Hoppe 1993, Martinez et al. 1996). Thus, small-scale variations in bacterial numbers and species composition can significantly alter the distribution of hydrolytic enzyme activities. Bacterial action on components of the organic matter field in the vicinity of phytoplankton influences carbon and nutrient fluxes in various pathways: microbial loop, sinking, grazing food chain, storage, and fixation (Azam 1998). For example, high hydrolytic activities of bacteria colonizing phytoplankton cells of macroscopic organic aggregates led to 'uncoupled solubilization' of exopolymers which reduced the sinking flux (Smith et al. 1992, Grossart \& Simon 1998). On the other hand, bacteria clustered around or attached to phytoplankton cells significantly enhanced (Bell \& Mitchell 1972) or reduced (Brussaard \& Riegman 1998) primary production by release or uptake of phytoplankton nutrients, respectively.

To study bacteria-phytoplankton interactions under more controlled conditions we have incubated 3 axenic marine diatoms (Cylindrotheca fusiformis, Nitzschia laevis, and Thalassiosira weissflogii) with specific bacterial isolates, mixed bacterial populations, and coastal seawater from Scripps Pier, La Jolla, USA. Bacterio- and phytoplankton growth as well as exopolymer production were followed during incubation of various cultures to characterize bacteria-phytoplankton interactions. In addition, potential hydrolytic ectoenzyme activities were measured to test the hypothesis that bacteria become highly metabolically active in the presence of living algae, dead algae, and polymer particles. Furthermore, we incubated phytoplankton and bacteria in a vitamin and trace metal free medium to test if various environmental conditions may alter bacteria-phytoplankton interactions.

\section{MATERIAL AND METHODS}

Study site and sampling. From June 1996 to March 1997 water was collected off Scripps Pier $\left(32^{\circ} 53^{\prime} \mathrm{N}\right.$, $117^{\circ} 15^{\prime} \mathrm{W}$ ) by lowering a $1 \mathrm{l}$ polycarbonate flask into the upper metres of the sea.

Bacterial isolates. Three bacterial strains of marine bacteria (Fl 2, Fl 3, and S 3) were used as test organisms isolated in fall and winter 1993 off Scripps Pier (Martinez et al. 1996). The frozen stocks were spread on agar plates (1.5\% wt/vol. agar, Difco) enriched with ZoBell 2216E medium (5 g peptone $+1 \mathrm{~g}$ yeast extract in $1 \mathrm{l}$ of $0.45 \mu \mathrm{m}$ pre-filtered seawater, autoclaved at $121^{\circ} \mathrm{C}$ for $30 \mathrm{~min}$ ) and grown overnight at $21^{\circ} \mathrm{C}$. To gain a sufficient number of bacteria all isolates were grown at $21^{\circ} \mathrm{C}$ in fluid ZoBell 2216E medium without agar overnight. Harvested bacteria were washed $3 \times$ by dialysis (12 h) in dialysis bags ( $\sim 0.3$ to $0.35 \mathrm{~nm}$, neoLab) filled with sterile artificial seawater (Darley \& Volcani 1969 ) or sterile Guillard seawater medium (f/2) to minimize input of bacteria-derived matter into the phytoplankton cultures.

In July 1996, 4 mixed populations of bacteria were obtained by incubating seawater of Scripps Pier in fluid ZoBell 2216E medium without agar (B 1) and in axenic cultures of Cylindrotheca fusiformis (B 2), Nitzschia laevis (B 3), and $N$. angularis (B 4). Bacteria and algae were separated by gravity filtration through $5.0 \mu \mathrm{m}$ polycarbonate filters (Nuclepore). To remove dissolved organic matter from the filtrate bacteria were rinsed with sterile seawater medium and concentrated by tangential flow filtration $(0.2 \mu \mathrm{m})$.

Axenic algal cultures. Axenic cultures of 3 marine diatoms (Cylindrotheca fusiformis, Nitzschia laevis, and Thalassiosira weissflogii) were obtained from Provasoli-Guillard National Center for Culture of Marine Phytoplankton (CCMP, Maine, USA). The algae were grown at $16^{\circ} \mathrm{C}$ in sterile artificial seawater (Darley \& Volcani 1969) or sterile Guillard seawater medium $(f / 2)$ in a $12: 12 \mathrm{~h}$ dark:light cycle at approximately

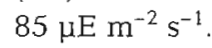

Growth of bacteria-phytoplankton cultures. Mixed cultures were obtained by adding $1 \mathrm{ml}$ of washed bacteria to diatom cultures immediately after transferring them to $20 \mathrm{ml}$ of fresh medium. The density of added diatoms was 2000 to 4000 cells $\mathrm{ml}^{-1}$ and that of bacteria 1 to $3 \times 10^{6}$ cells $\mathrm{ml}^{-1}$. Bacterial growth in monospecific and mixed cultures was followed by cell counting (see 
Table 1. Histochemical dyes and procedures used to stain free and surface-bound exopolymers in pure and mixed cultures of bacteria and diatoms

\begin{tabular}{|c|c|c|c|}
\hline Dye & Protocol & Specificity & Source \\
\hline Toluidine Blue (TB) & $\begin{array}{l}\text { TB (final conc. } 0.1 \% \text { ) in na- } \\
\text { acetate buffer at pH } 4.2 \text {, } \\
5.0, \text { and } 5.6\end{array}$ & $\begin{array}{l}\text { Proteoglycanes } \\
\text { Acid polysaccharides } \\
\text { Highly polymeric } \\
\text { Molecules, e.g. DNA }\end{array}$ & Chayen et al. (1973) \\
\hline Alcian Blue (AB) & $\begin{array}{l}\mathrm{AB}(8 \mathrm{GX} \text {, final conc. } \\
0.05 \%) \text { in na-acetate } \\
\text { buffer at pH } 5.8\end{array}$ & Acid polysaccharides & Logan et al. (1994) \\
\hline Comassie Blue (CB) & $\begin{array}{l}\mathrm{CB}(\mathrm{G}-250 \text {, final conc. } \\
0.04 \%) \text { in filtered sea- } \\
\text { water at } \mathrm{pH} 7.0\end{array}$ & Proteins & Long \& Azam (1996) \\
\hline FITC labeled lectins & $\begin{array}{l}\text { Lectins (final conc. } 0.001 \% \text { ) } \\
\text { in } 50 \mathrm{mM} \text { TRIS buffer } \\
\text { plus } 2 \mathrm{M} \mathrm{NaCl} \text { and } \mathrm{CaCl}_{2} \text {, } \\
\mathrm{MnCl}_{2}, \mathrm{MgCl}_{2} \text { (ea. } 1 \mathrm{mM}^{2}\end{array}$ & Carbohydrates & Liener et al. (1986) \\
\hline $\begin{array}{l}\text { (a) Concanavalin A } \\
\text { (b) Bandeiraea s. II } \\
\text { (c) Glycine max } \\
\text { (d) Wheat germ }\end{array}$ & & $\begin{array}{l}\text { a-man, a-glc } \\
\text { glnNAc } \\
\text { galNAc } \\
\text { glcNAc, neuNAc }\end{array}$ & \\
\hline
\end{tabular}

below) whereas that of diatoms was monitored in a fluorometer (Beckman, USA), which measured the autofluorescence of chlorophyll a. Phytoplankton growth is given as relative fluorescence since it was linearly correlated to Thalassiosira weissflogii cell numbers for more than $300 \mathrm{~h}$ of incubation $\left(\mathrm{r}^{2}=0.98, \mathrm{n}=12\right)$. This holds also true for Cylindrotheca fusiformis but chlorophyll a content per cell and cell growth were much higher as compared to $T$. weissflogii and Nitzschia laevis (data not shown). Cultures were continously shaken at low speed to prevent sedimentation and accumulation of cells at the bottom of the tube. To test whether bacteria-phytoplankton interactions change with stress we incubated $C$. fusiformis and $N$. laevis in f/ 2 medium missing vitamins and trace metals. All cultures were kept at $16^{\circ} \mathrm{C}$ in a $12: 12 \mathrm{~h}$ dark:light cycle at approximatey $85 \mu \mathrm{E} \mathrm{m} \mathrm{m}^{-2} \mathrm{~s}^{-1}$.

Numbers of bacteria and algae. Two-hundred $\mu l$ samples were diluted 1:10 in sterile filtered seawater, fixed with $0.2 \mu \mathrm{m}$ pre-filtered, borate-buffered formalin ( $2 \%$ final), and stained with $4{ }^{\prime}, 6$-diamidino-2phenylindole (DAPI; $1 \mu \mathrm{g} \mathrm{ml}^{-1}$ final conc.) for $3 \mathrm{~min}$. Thereafter, samples were filtered onto $0.2 \mu \mathrm{m}$ poresized black polycarbonate filters (Nuclepore) and bacterial numbers were determined by epifluorescence microscopy at $1250 \times$ (Porter \& Feig 1980). For counting algae $2 \mathrm{ml}$ of sample were fixed, stained, and filtered onto $5.0 \mu \mathrm{m}$ pore-sized polycarbonate filters (Nucleopore). Algal numbers were counted at $500 \times$ magnification using the DAPI and blue light filter set to detect the autofluorescence of chlorophyll a. All samples were usually counted within a few hours after sampling.

Staining of algal and bacterial exopolymers. To detect free and surface-bound exopolymers during incubation of pure and mixed cultures of bacteria and diatoms various histochemical staining procedures were used (Table 1). For staining with Toluidine Blue, Alcian Blue, and Comassie Blue, aliquots of 1 to $5 \mathrm{ml}$ were filtered onto $0.2 \mu \mathrm{m}$ pore-sized polycarbonate filters (Nuclepore). Filters were mounted on frosted slides (Cytoclear ${ }^{\mathrm{TM}}$, Poretics Corp., CA, USA) and examined with light microscopy. In contrast, staining with lectins directly took place in $100 \mu$ l subsamples. Further details of all protocols used for staining are given in references of Table 1.

Hydrolytic ectoenzyme activities. Leucine aminopeptidase (Leu-AMP) and $\beta$-glucosidase ( $\beta$-GlcAse) activities were measured by using L-leucine-methyl coumarinylamide (MCA, aminopeptidase) and methyl umbelliferyl $\beta$-D-glucoside (MUF, $\beta$-glucosidase) as fluorogenic substrate analogs (Hoppe 1993). Hydrolytic ectoenzyme activities were measured by incubation of $5 \mathrm{ml}$ subsamples with analogs at saturating concentration $\left(250 \mu \mathrm{M}\right.$ final conc.) for $1 \mathrm{~h}$ at $16^{\circ} \mathrm{C}$ in the dark. A heat-killed sample $\left(80^{\circ} \mathrm{C}\right.$ for $\left.20 \mathrm{~min}\right)$ served as control. Fluorescence was measured at $380 / 365 \mathrm{~nm}$ excitation and $440 / 455 \mathrm{~nm}$ emission for MUF/MCA substrates, respectively, in a Hoefer TKO-100 fluorometer. Cell specific activities were calculated by dividing the volume specific ectoenzyme activities by corresponding bacterial numbers. 


\section{RESULTS}

\section{Bacterial and algal growth in $f / 2$ medium}

Cell numbers of Thalassiosira weissflogii almost exponentially increased until more than $300 \mathrm{~h}$ of incubation in $f / 2$ seawater medium (Fig. 1). Phytoplankton growth was significantly higher whenever bacteria were present. Addition of the bacterial isolate $S 3$ led to the most pronounced increase in phytoplankton growth and resulted in almost twice the algal cell number as compared to axenic cultures.

In parallel, bacterial numbers of single isolates were significantly higher when incubated together with the diatom as compared to $f / 2$ seawater medium without any organic material (Fig. 1). In all bacteria-phytoplankton cultures, increase in bacterial numbers was strongest during the first $100 \mathrm{~h}$ of incubation. Thereafter, cell numbers of the bacterial isolate $\mathrm{Fl} 2$ remained almost the same whereas those of Fl 7 and S 3 further increased until the end of the experiment. Abundances of $\mathrm{Fl} 7$ and $\mathrm{Fl} 2$ in $f / 2$ medium only slightly increased during the first $50 \mathrm{~h}$ of incubation

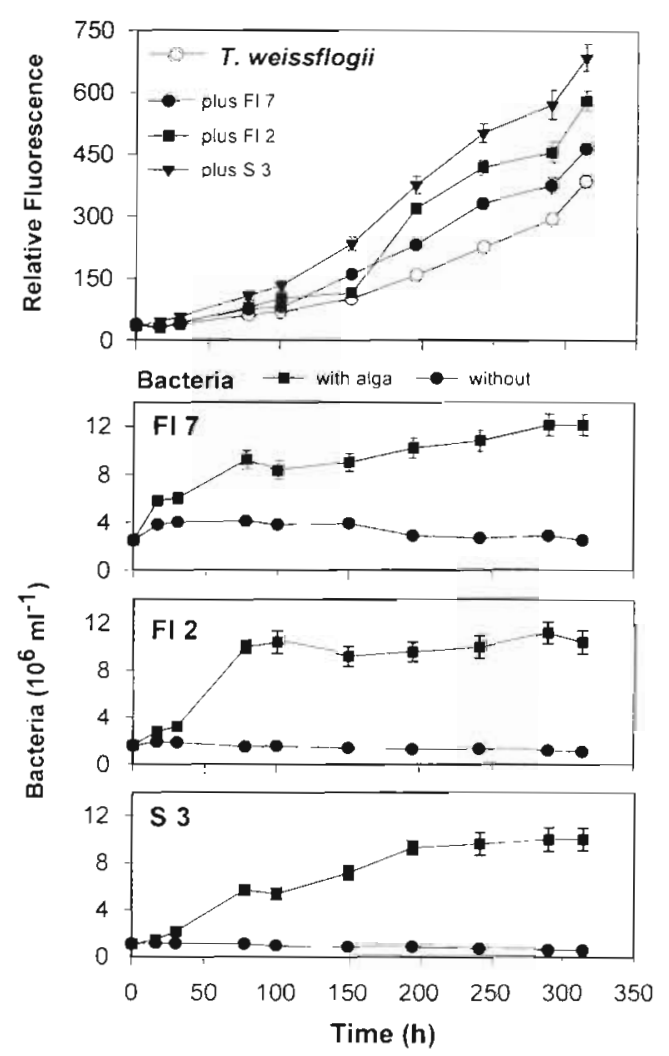

Fig. 1. Relative fluorescence of Thalassiosira weissflogii incubated without and with bacterial isolates (Fl 7, FI 2, and S 3) and bacterial numbers of the 3 isolates incubated without and with alga

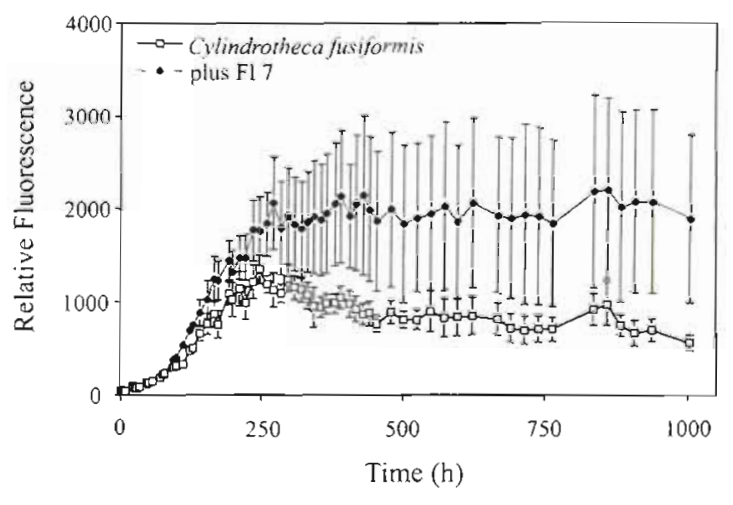

Fig. 2. Relative fluorescence of Cylindrotheca fusiformis incubated in $f / 2$ medium with and without a bacterial isolate (Fl 7 )

whereas that of S 3 did not show any increase. In all diatom-free cultures bacterial numbers continuously decreased after $100 \mathrm{~h}$ of incubation.

Cell numbers of Cylindrotheca fusiformis were continuously higher when incubated together with Fl 7 for $1000 \mathrm{~h}$ (Fig. 2) even though of all tested bacterial isolates Fl 7 had the lowest stimulation on growth of Thalassiosira weissflogii. Cell densities of $C$. fusiformis in axenic culture were maximal after $250 \mathrm{~h}$ and decreased thereafter. In contrast, in the presence of $\mathrm{Fl} 7$ algal numbers were highest after more than $270 \mathrm{~h}$ and remained at almost the same level thereafter suggesting an equilibrium between phytoplankton growth and bacterial remineralization of nutrients. The high standard deviation in relative fluorescence of $C$. fusiformis in the presence of $\mathrm{Fl} 7$ was due to significantly lower algal numbers in one of 3 parallels.

Maximum growth yield of Cylindrotheca fusiformis in $f / 2$ medium was increased by 43 to $92 \%$ when the alga was incubated with mixed populations of bacteria isolated from seawater off Scripps Pier. Interestingly, seawater bacteria grown and isolated on axenic marine diatoms had a more pronounced effect on algal growth than those isolated on ZoBell 2216E medium ( 73 to $92 \%$ and $43 \%$ higher algal growth yield, respectively). In contrast to the previous experiment, maximum algal density in axenic culture was reached after $480 \mathrm{~h}$ and persisted until $700 \mathrm{~h}$ of incubation, indicating different growth conditions in both experiments. However, maximum algal density in mixed populations occurred even later (>550 h).

Nitzschia laevis grown in $f / 2$ medium together with Fl 7 also showed significantly higher algal numbers as compared to axenic cultures (Fig. 3). When adding Fl 7 to an axenic culture in the stationary growth phase (after $400 \mathrm{~h}$ ) a further increase in cell number up to the level of an initially mixed culture occurred. Again, maxima in algal number were persistent in the presence of $\mathrm{Fl} 7$. 


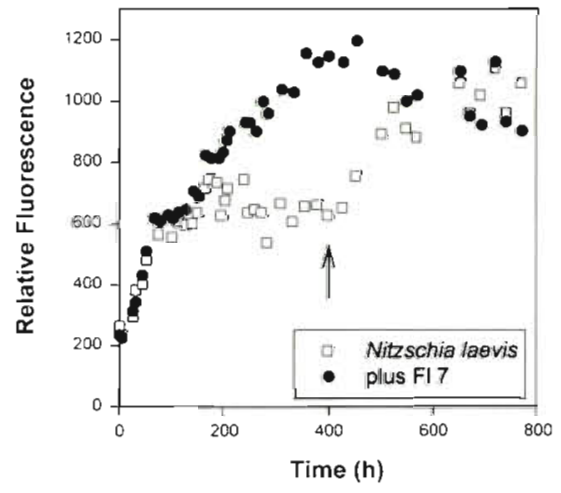

Fig. 3. Relative fluorescence of Nitzschia laevis incubated in $f / 2$ medium without and with a seawater bacterium (Fl 7). ( $\uparrow$ )

Time point when Fl 7 was added to the axenic control

\section{Bacterial and algal growth in artificial seawater}

The growth pattern of Cylindrotheca fusiformis in artificial seawater (Fig. 4) was dramatically changed as compared to that in $f / 2$ medium. In axenic culture maximum algal numbers occurred after $>350 \mathrm{~h}$ and rapidly decreased thereafter. In mixed cultures numbers of $C$. fusiformis peaked between 350 and $390 \mathrm{~h}$ but also strongly decreased thereafter. In contrast to incubations in $f / 2$ medium, bacterial populations grown and isolated on ZoBell 2216E medium (B 4) led to strongest stimulation of algal growth. Artificial seawater contains $5 \mathrm{mM}$ glycylglycine and, thus, offers good conditions for growth of heterotrophic bacteria such as those selected on nutrient-rich ZoBell 2216E medium. Bacterial numbers in all mixed populations were extremely high and reached up to $5.2 \times 10^{9}$ cells $\mathrm{ml}^{-1}$, approximately 2 orders of magnitude higher than in $f / 2$ medium.

\section{Algal growth in vitamin and trace metal free f/2 medium}

In contrast, incubation of Cylindrotheca fusiformis in vitamin and trace metal free $f / 2$ medium resulted in no visible algal growth (Fig. 5). The addition of the bacterial isolate Fl 7 led to a slight increase and consecutive slight decrease in algal cell number. In contrast, addition of the marine isolate Fl 2 and of natural assemblages of seawater bacteria off Scripps Pier resulted in a steady decline of relative fluorescence, suggesting reduced nutrient availability or even a parasitic relationship between bacteria and algae.

Incubation of axenic Nitzschia laevis under the same limiting conditions led to cell growth (Fig. 5) which was much reduced as compared to non-limiting conditions

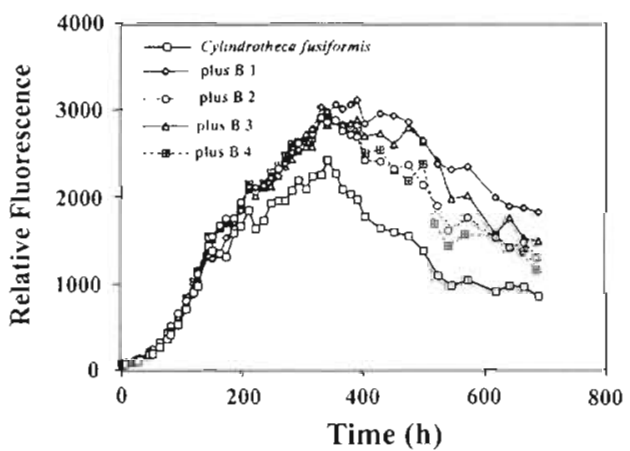

Fig. 4. Relative fluorescence of Cylindrotheca fusiformis incubated in artificial seawater rich in organics without and with 4 bacterial populations from Scripps Pier (B 1, B 2, B 3, and B 4, see 'Results')

(Fig. 3). The addition of bacterial isolates and fresh seawater did not result in a complete stop but in reduced algal growth. Again, the presence of bacteria had a negative effect on algal growth under the given limiting conditions.

\section{Exopolymer production}

Lectine staining in all algal cultures revealed enhanced concentrations of exopolysaccharids in the presence of bacteria on the surface of cells with reduced autofluorescence or in cell aggregates (Fig. 6) in mixed cultures. Cells with bright autofluorescence

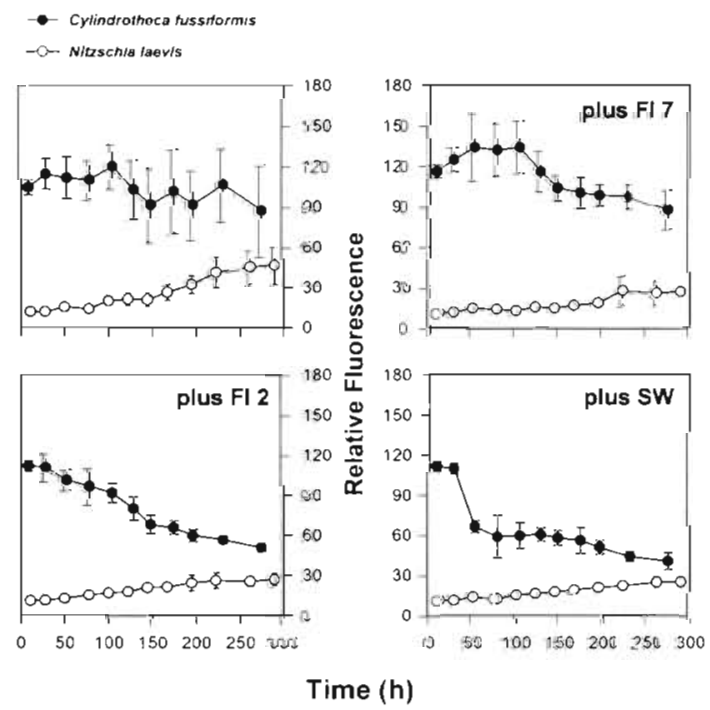

Fig. 5. Relative fluorescence of Cylindrotheca fusiformis and Nitzschia laevis incubated in $f / 2$ medium free of vitamins and trace metals without and with bacterial isolates $(\mathrm{Fl} \mathrm{7}, \mathrm{Fl} \mathrm{2}$, and SW) 

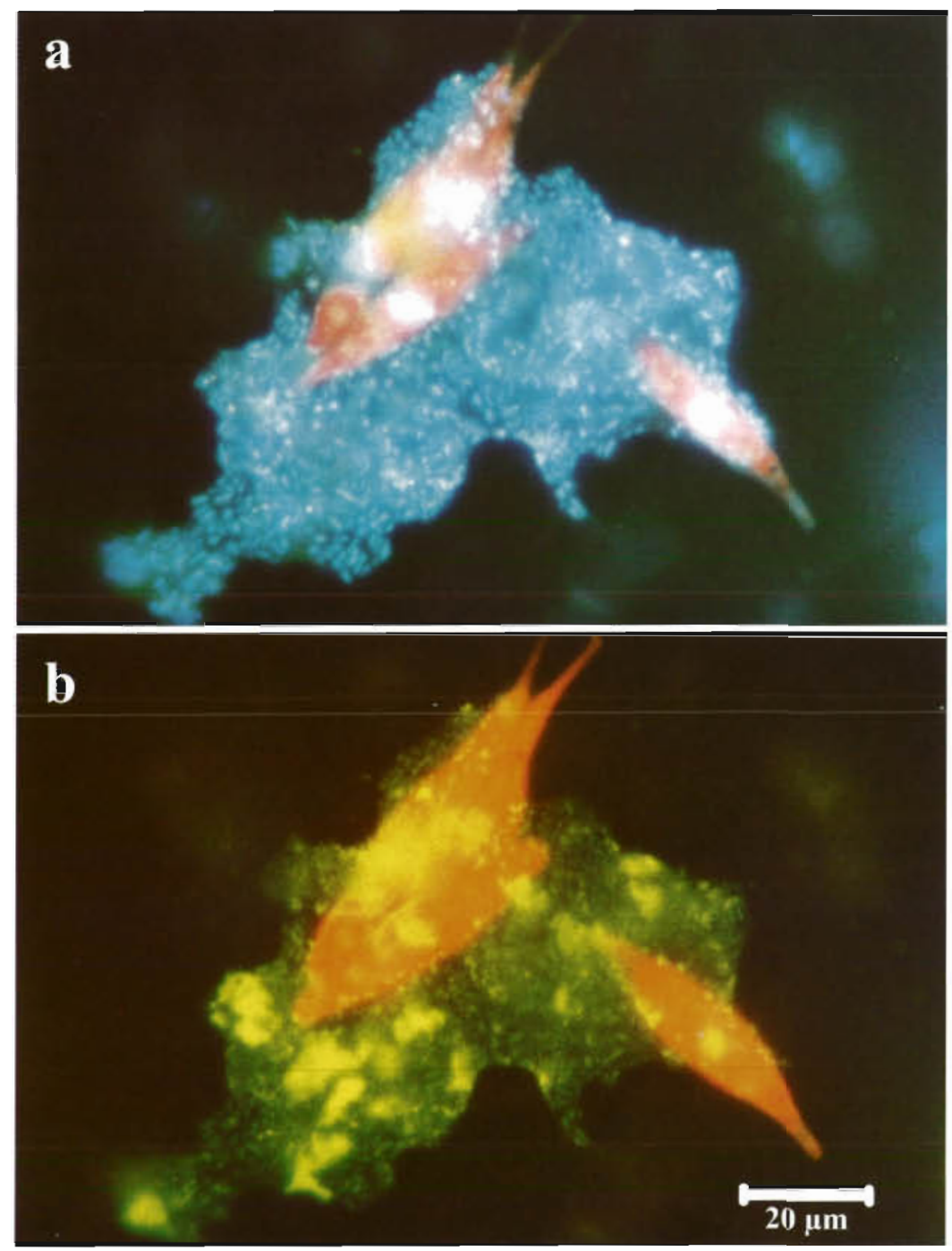

Fig. 6. Exopolymer production after $12 \mathrm{~h}$ of incubation of Cylindrotheca fusiformis and the seawater bacterium Fl 7 . (a) DAPI staining. (b) Concanavalin A staining. Epifluorescence micrograph (1000× magnification)

only showed a thin layer of Concanavalin A stainable material in the absence and presence of bacteria whereas all other lectines (Bandeiraea s. II, Glycine max., and Wheat germ) did not stain at all. In contrast, small amounts of material stainable with Bandeiraea s. II, Glycine max, and Wheat germ were found on algal cells and algal aggregates both with dense bacterial colonization. Changes in the quality of exopolymer material according to the degree of bacterial colonization may also reflect production and degradation of exopolymers by bacteria. However, mucus and cells of the bacterial isolate Fl 7 in ZoBell $2216 \mathrm{E}$ medium were only stainable with Concanavalin A.

Staining with Toluidine Blue also revealed high amounts of exopolymers on the surface of algal cells with reduced autofluorescence and in cell aggregations. In all axenic cultures a continuous increase in the amount of free and cell-bound exopolymer material was observed whereas in mixed cultures no uniform trend was found.

Staining with Alcian Blue and Coomassie Blue yielded a complex pattern during different incubations: In axenic cultures of Cylindrotheca fusiformis free particles of both acid polysaccharides (TEP: transparent exopolymer particles) and proteins (CSP: Comassie Blue stainable particles) accumulated during phytoplankton growth (Fig. 7a). Initial concentrations of TEP and CSP were relatively high and may be introduced with the inoculated algae. In pure cultures of $\mathrm{Fl}$ 7 numbers of TEP and CSP increased during bacterial growth whereby the increase in TEP was much higher than in CSP (Fig. 7b). TEP and CSP almost completely disappeared in parallel to a strong decrease in bacterial numbers. Some TEP and CSP might be also intro- 

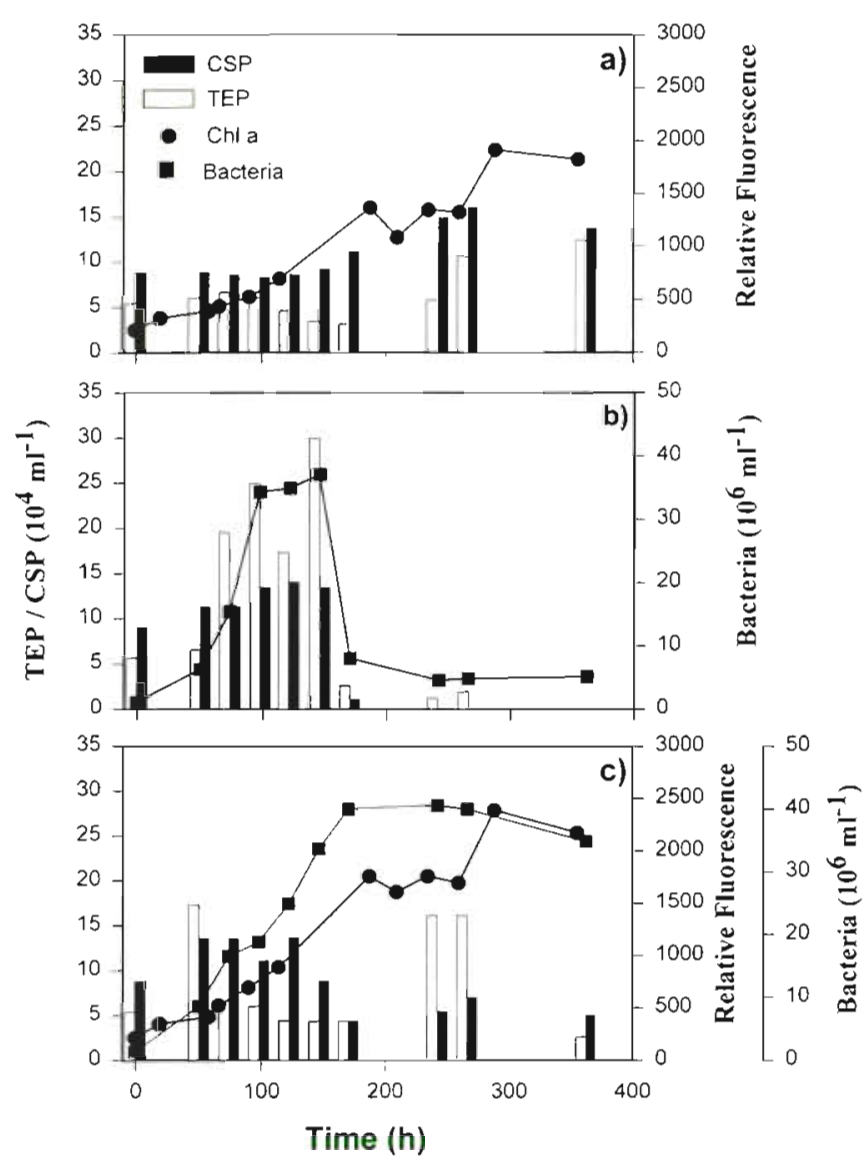

Fig. 7. Abundance of transparent exopolymer particles (TEP) and of Comassie Blue stainable particles (CSP), relative fluorescence, and bacterial numbers in axenic and mixed cultures of Cylindrotheca fusiformis and the seawater bacterium Fl 7. All parameters were measured in triplicate and mean values varied within 5 to $15 \%$. (a) Axenic culture of $C$. fusiformis. (b) Pure culture of Fl 7. (c) Mixed culture of C. fusiformis and Fl 7

duced with the inocculum since particles $>0.3 \mathrm{~nm}$ could not be separated by dialysis. In mixed cultures of C. fusiformis and Fl 7, numbers of TEP peaked at $50 \mathrm{~h}$ and 250 to $270 \mathrm{~h}$ whereas those of CSP were highest at 50 to $120 \mathrm{~h}$ and were only slightly enhanced at 250 to $370 \mathrm{~h}$ of incubation (Fig. $7 \mathrm{c}$ ). Bacterial numbers remained constant or slightly decreased after $170 \mathrm{~h}$ whereas those of the algae increased until $290 \mathrm{~h}$.

In mixed cultures of Cylindrotheca fusiformis and B 2 numbers of TEP peaked at 50 to $70 \mathrm{~h}$ and at 250 to $370 \mathrm{~h}$ whereas those of CSP remained highest at 50 to $120 \mathrm{~h}$ and were only slightly enhanced at 250 to $370 \mathrm{~h}$ (Fig. 8a). Both algae and bacteria continuously increased until $290 \mathrm{~h}$ of incubation. Mixed cultures of $C$. fusiformis and B 3 (Fig. 8b) or B 4 (Fig. 8c) had comparable low numbers of TEP at 50 to $70 \mathrm{~h}$. In addition, in cultures with B 4 higher numbers of TEP occurred at 250 to $370 \mathrm{~h}$. In contrast, numbers of CSP in all cultures

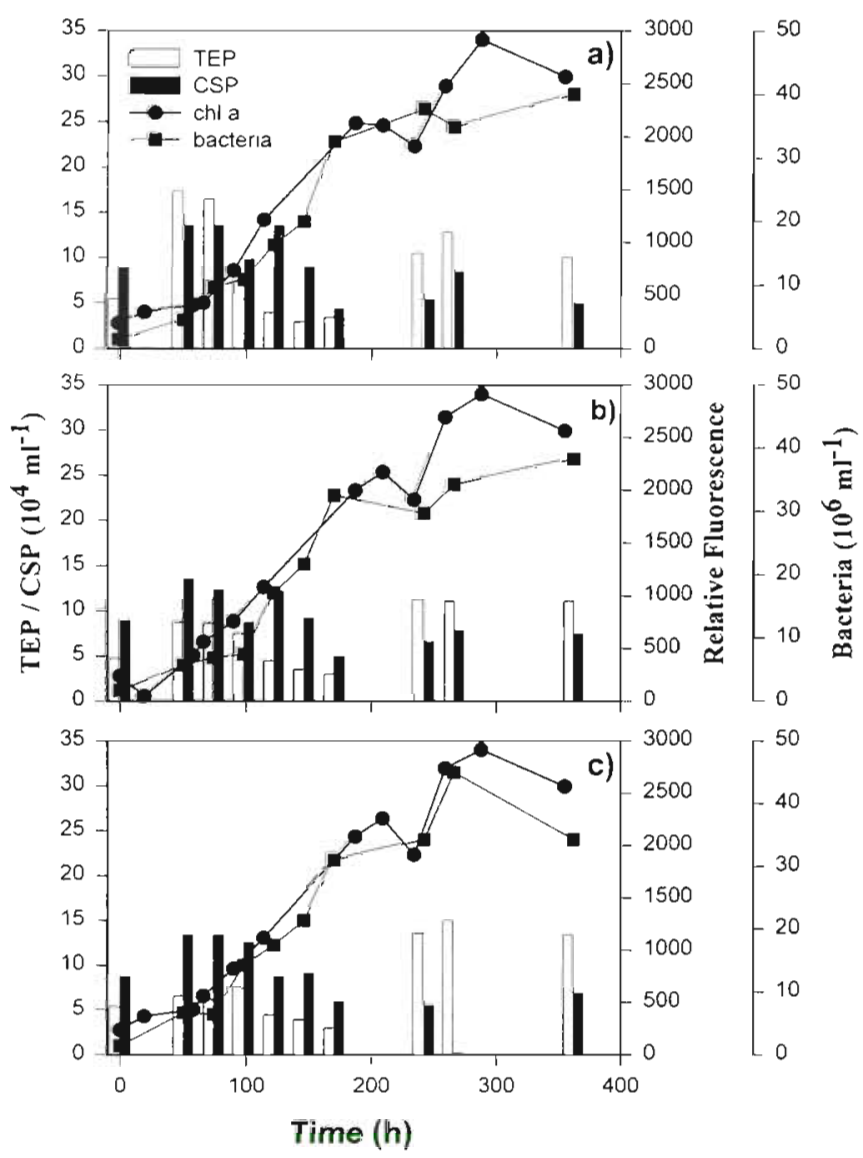

Fig. 8. Abundance of transparent exopolymer particles (TEP) and of Comassie Blue stainable particles (CSP), relative fluorescence, and bacterial numbers in mixed cultures of $C_{y}$ lindrotheca fusiformis and seawater populations: (a) B 2, (b) B 3 , and (c) B 4 (see 'Results'). All parameters were measured in triplicate and average values varied within 5 to $15 \%$

were almost the same. The comparison of axenic (Fig. $7 \mathrm{a}$ ) and mixed cultures (Figs. 7b,c \& 8a-c) shows that abundance of CSP in mixed cultures increased between 50 and $120 \mathrm{~h}$ and was much lower after a steep decline at 120 to $170 \mathrm{~h}$. TEP were almost always more abundant in mixed than in axenic cultures. In contrast to axenic cultures, abundance of TEP in bacterial and mixed cultures showed a first peak at 50 to $100 \mathrm{~h}$, which was highly variable in the various cultures. In all mixed cultures a further peak of TEP appeared at 250 to $270 \mathrm{~h}$.

\section{Hydrolytic ectoenzyme activity}

Aminopeptidase activity in cultures of Cylindrotheca fusiformis and bacteria increased dramatically during incubation (Fig. 9). The most pronounced increase in 


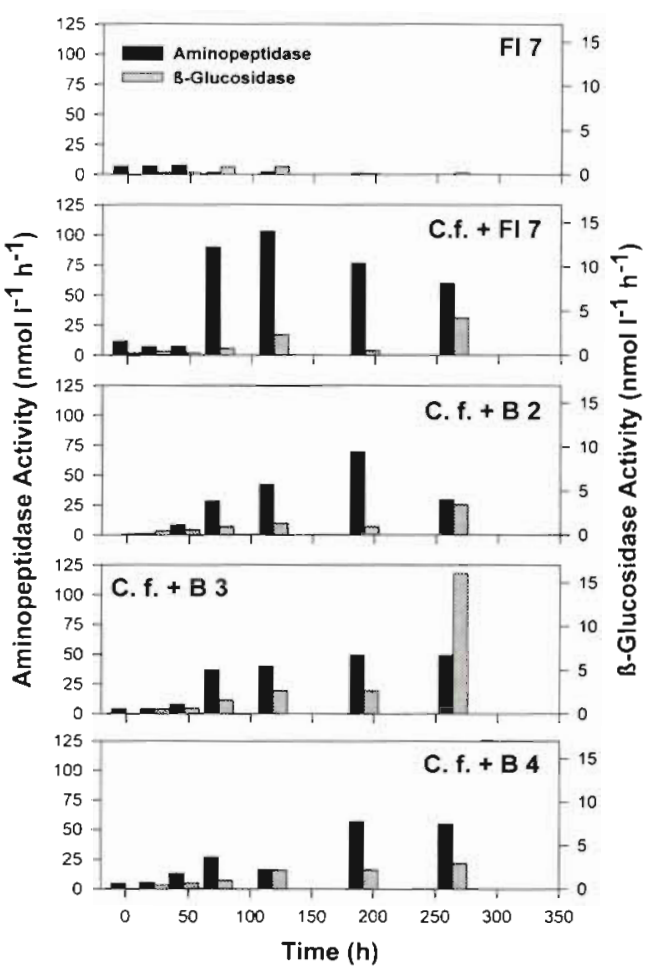

Fig. 9. Activities of aminopeptidase and $\beta$-glucosidase in a pure culture of $\mathrm{Fl} 7$ and in mixed cultures of bacterial isolates (Fl 7, B 2, B 3, and B 4) and Cylindrotheca fusiformis in $\mathrm{f} / 2$ seawater medium

total as well as cell specific proteolytic activity occurred after $70 \mathrm{~h}$ but was highly variable in different cultures. Total and cell specific activities were highest in cultures with $\mathrm{Fl} 7$. In contrast, $\mathrm{Fl} 7$ in $f / 2$ medium without algae showed an increase in cell specific aminopeptidase activity until $50 \mathrm{~h}$ when numbers of CSP were high. Later it decreased to almost zero at the end of the experiment when no CSP were detected. High proteolytic activities in mixed cultures, especially with Fl 7, may explain a reduced accumulation of protein particles during incubations.

Activity of $\beta$-GlcAse was significantly lower and more variable in different cultures (Fig. 9) as compared to that of aminopeptidase. Increased total and cell specific activity of $\beta$-GlcAse in pure cultures of $F 17$ were measured at $50 \mathrm{~h}$ when concentrations of free TEP were high. After $50 \mathrm{~h}$ total and cell specific $\beta$-GlcAse activities in mixed cultures were higher than in pure cultures and may explain the consecutive decrease in TEP number. In contrast, total as well as cell specific $\beta$-GlcAse activities in mixed cultures with B 2 and B 4 were relatively low but slightly increased during incubation. Mixed cultures with B 3 showed an extreme increase in total and cell specific $\beta$-GlcAse activity after $270 \mathrm{~h}$. The lower activity of $\beta$-GlcAse as compared to that of aminopeptidase may explain the higher abundance of TEP than that of CSP at 250 to $270 \mathrm{~h}$.

\section{DISCUSSION}

Our study shows that interactions between specific bacteria $(F 17, F 12$, or natural populations of seawater bacteria) and a marine diatom (Cylindrotheca fusiformis, Thalassiosira weissflogii, or Nitzschia laevis) strongly depend on the varying environmental conditions. Media rich in inorganic but without organic nutrients led to enhanced growth of both bacteria and algae in mixed as compared to single bacterial or algal cultures (Fig. 1). Media rich in organic nutrients increased bacterial abundance by 2 orders of magnitude as compared to media without organic nutrients. Algal growth in media rich in organic nutrients was also enhanced in the presence of bacteria but bacterial and algal numbers never reached a steady state as observed for media without any organic nutrients (Fig. 2). Stressing phytoplankton by incubation in media free of vitamins and trace metals led to lower algal growth or even reduction in living cells when bacteria were present (Fig. 5).

Stimulation of microbial activity by phytoplanktonic release of extracellular products has been shown by Bell et al. (1974), supporting the 'phycosphere' as a useful concept in discussing bacteria-phytoplankton interactions in aquatic environments. In the 'phycosphere' bacterial growth is directly stimulated by extracellular products of the alga (Wang \& Priscu 1994a). Following continuous production and excretion of dissolved organic matter by phytoplankton, utilizable for bacteria, Azam \& Ammerman (1984) formulated the 'cluster' hypothesis. Bacterial mineralization of the relatively $\mathrm{N}$ - and P-rich lysed algal cellular components (Garber 1984, Caron et al. 1988, Jürgens \& Güde 1990, Goldman \& Dennett 1991) is supposed to be an important process for supplying algae with ammonium or phosphate (Brussaard \& Riegman 1998). Increasing ectoenzyme activities, especially of aminopeptidase, throughout our study (Fig. 9) indicate enhanced bacterial mineralization of algal detritus and particles which are rich in carbon and nitrogen. Since there were no protozoa present in any of our incubations stimulation of nutrient-limited phytoplankton by bacterivorous flagellate grazing (Rothhaupt 1992) can be excluded. Stimulation of algal growth observed in our relatively simple laboratory systems is, thus, only the result of bacterial action.

Furthermore, phytoplankton growth can be also enhanced by stimulatory substances which are not of direct bacterial origin but can be released during microbial colonization and degradation of senescent algae. In all mixed cultures, and in cell aggregations, 
cells with reduced autofluorescence were densely colonized by bacteria which possibly released stimulatory substances such as cytokins. On the other hand, high microbial activities in aggregates and detritus lead to release of nitrate and ammonium (Paerl \& Pinckney 1996), phosphorus (see above), and $\mathrm{CO}_{2}$, which increase and sustain algal growth in mixed cultures. In the presence of the bacterial isolate $\mathrm{Fl} 7$ the relative fluorescence of Cylindrotheca fusiformis remained at almost maximum value for $>1000 \mathrm{~h}$ of incubation whereas that of axenic cultures strongly decreased (Fig. 2). This indicates that microbial action even of a single isolate $(\mathrm{Fl} 7)$ is sufficient to sustain enhanced growth of the diatom for a prolonged period of time.

Under in situ conditions, however, competition between algae and aquatic bacteria for limiting nutrients such as phosphate (Rhee 1972, Currie \& Kalff 1984, Thingstad et al. 1993, Guerrini et al. 1998) frequently occurs. Bacterioplankton growth can be directly limited by inorganic $\mathrm{P}$ and $\mathrm{N}$ when these elements are in short supply (Wang \& Priscu 1994b). In media without organic nutrients, increase in organic matter and simultaneous reduction in inorganic nutrients due to high algal and bacterial production led to a symbiotic relationship between bacteria and algae. However, in artificial seawater enriched with glycylglycine no steady state between algal and bacterial production could be observed. Extremely high concentrations of bacteria $\left(5.2 \times 10^{9}\right.$ cells $\left.\mathrm{ml}^{-1}\right)$ in artificial seawater enhanced turbidity, bacterial colonization of algal cells, and presumably competition for inorganic nutrients. Eutrophication increases input of organic matter, which may result in high bacterial biomass and subsequent reduction of phytoplankton health and biomass. In addition, a tremendous number of viruses were found in estuarine and other eutrophic environments (Cochran et al. 1998), indicating that prophage induction can further reduce health and biomass of phytoplankton in these environments.

Phytoplankton growth in vitamin and trace metal free $f / 2$ media was much lower (Nitzschia laevis) or even zero (Cylindrotheca fusiformis) as compared to media replenished with vitamins and trace metals. Bacteria which enhanced and sustained phytoplankton growth under nutrient-rich conditions reduced algal growth and biomass when vitamins and trace metals were absent. Microscopical observations revealed very dense colonization of the cell surface of the already stressed phytoplankton whereas the cell surface of healthy phytoplankton is hardly colonized by bacteria (Cole 1982). This demonstrates that bacteriaphytoplankton interactions of the same species are not constant and alter with changes of environmental conditions. In addition, under axenic culture conditions algal cell lysis is directly affected by the degree of nutrient deficiency (Brussaard et al. 1997) and the presence of bacteria can further increase phytoplankton stress by competition for limiting nutrients and increased phytoplankton lysis

Various marine algae prevent bacterial colonization of their cell surfaces by the production of antibacterial substances (Sieburth 1964, Kellam \& Walker 1989, Sastry \& Rao 1994). The extent of antibiotics production depends on phytoplankton activity and, thus, is reduced in stressed cells. As a result bacterial colonization will increase on algae growing under stress conditions such as vitamin and trace metal depletion. In natural bacterial communities there are certain species known which directly attack and lyse marine phytoplankton including diatoms (Imai et al. 1993). The shape of bacteria-phytoplankton interactions, thus, controls primary production to a varying degree, depending on the environmental conditions present.

Depending on bacteria-phytoplankton interactions the extent and quality of phytoplanktonic carbon release may dramatically change, resulting in temporarily enhanced or decreased carbon transfer to higher trophic levels. Algal carbon exudation in the form of TEP and CSP was increased in the presence of bacteria. Polysaccharide production of Cylindrotheca fusiformis was significantly increased in the presence of bacteria even though diatom cell growth was not negatively affected. On the other hand, bacteria can produce significant amounts of exopolymers such as polysaccharides (Grobben et al. 1998) and a large fraction of bacterial glucose uptake is incorporated into capsules when seawater bacteria are not C-limited (Stoderegger \& Herndl 1998). Production of TEP and CSP in pure cultures of Fl 7 were extremely high between 50 and $150 \mathrm{~h}$ of incubation, but with increasing starvation numbers of TEP and CSP dramatically decreased. This indicates that depending on environmental conditions bacteria are able to produce and also to degrade various amounts of exopolymeric matter.

In general, hydrolytic ectoenzyme activities were significantly enhanced in mixed cultures as compared to pure cultures of $\mathrm{Fl} 7$ which only showed low aminopeptidase and $\beta$-GlcAse activities. However, in the presence of artificial substrate analoga $\mathrm{Fl} 7$ is characterized by high aminopeptidase and relatively low $\beta$-GlcAse activity (Martinez et al. 1996). Preferential hydrolysis of proteins by bacteria in contrast to polysaccharides has been shown for different environments, e.g. macroscopic organic aggregates (Grossart \& Simon 1998). The preferential hydrolysis of CSP rich in N may explain the usually lower accumulation of CSP compared to TEP at 250 to $270 \mathrm{~h}$ of incubation. This indicates that high bacterial mineralization of organic nitrogen occurred in these experiments, which presumably increased and sustained phytoplankton growth. 
The high variability in production and in quality of exopolymers was also detected by lectine staining. Enhanced concentrations of exopolysaccharides on the surface of algae with reduced autofluorescence and in aggregates in the presence of dense bacterial colonization suggest changes in phytoplankton polysaccharide production due to the presence of bacteria. P limitation increases polysaccharide production not only of algae but also of heterotrophic bacteria (Mohamed et al. 1998). Polysaccharides stainable with Bandeiraea s. II, Glycine max, and Wheat germ were only found on algal cells and aggregates with dense bacterial colonization, indicating modifications of exopolysaccharides by bacterial production and ectoenzyme activity.

Modification of exopolymeric material by bacteria could result in slow-to-degrade polymeric but also dissolved organic matter (Azam 1998) and, thus, enhance carbon storage. Bacterial action on exopolymeric matter in microzones such as the 'phycosphere' will change ocean basin-scale carbon fluxes: microbial loop, sinking, grazing, storage, and fixation. Changes in bacteriaphytoplankton interactions due to environmental conditions such as eutrophication and pollution may have huge impacts on global carbon cycling but are largely neglected in ecosystem management and modelling (Azam et al. 1998). Our very simple laboratory system shows that bacteria-phytoplankton interactions are highly variable with environmental conditions and may be even more complex in natural systems.

Acknowledgements. This work was in part supported by NSF grants to F. Azam. Thanks to all people in the Azam lab for lab assistance and discussion. Special thanks to K. Bidle for providing axenic cultures of Thalassiosira weissflogii and L. Riemann for intense discussions. This work was supported by a postdoctoral fellowship given by the Deutsche Forschungsgemeinschaft (DFG) to H.-P.G.

\section{LITERATURE CITED}

Azam F (1998) Microbial control of oceanic carbon flux: the plot thickens Science 280:694-696

Azam F, Ammerman JW (1984) Cycling of organic matter by bacterioplankton in pelagic marine ecosystems: microenvironmental considerations. In: Fasham MJR (ed), Flows of energy and materials in marine ecosystems. Plenum Publishing Corporation, New York, p 345-360

Azam F, Fandino LB, Grossart HP, Long RA (1998) Microbial loop: its significance in oceanic productivity and global change. CIEMS [6] B1

Barbeyron T, Berger Y (1989) Commensal bacteria living with two multicellular marine algae: Antithamnion plumula (Ellis) Thuret and Cladophora rupestris (L.) Kützing (Linné), Kützing. Phenotypic characterization. Cah Biol Mar 30:361-374

Bell W, Mitchell R (1972) Chemotactic and growth responses of marine bacteria to algal extracellular products. Biol Bull 143:265-277

Bell WH, Lang JM, Mitchell R (1974) Selective stimulation of marine bacteria by algal extracellular products. Limnol Oceanogr 19:833-839

Blackburn N, Azam F, Hagström $\AA$ (1997) Spatially explicit simulations of a microbial food web. Limnol Oceanogr 42 613-622

Brussaard CPD, Riegman R (1998) Influence of bacteria on phytoplankton cell mortality with phosphorus or nitrogen as the algal-growth-limiting nutrient Aquat Microb Ecol $14: 271-280$

Brussaard CPD, Noordeloos AAM, Riegman R (1997) Autolysis kinetics of the manine diatom Ditylum brightwellii (Bacillariophyceae) under limitation and starvation of nitrogen and phosphorus J Phycol 33:980-987

Caldwell DE (1977) The planktonic microflora of lakes. Crit Rev Microbiol 5:305-370

Caron DA, Goldman JC, Dennett MR (1988) Experimental demonstration of the roles of bacteria and bacterivorous protozoa in plankton nutrient cycles Hydrobiologia 159:27-40

Chayen J, Bitensky L, Butcher RG (1973) Practical histochemistry. John Wiley \& Sons, New York

Cochran PK, Kellogg CA, Paul JH (1998) Prophage induction of indigenous marine lysogenic bacteria by environmental pollutants. Mar Ecol Prog Ser 164:125-133

Cole JJ (1982) Interactions between bacteria and algae in aquatic ecosystems. Annu Rev Ecol Syst 13:291-314

Currie DJ, Kalff J (1984) Can bacteria outcompete phytoplankton for phosphorus? A chemostat test. Microb Ecol 10:205-216

Darley WM, Volcani BE (1969) Artificial sea water medium for diatoms. Exp Cell Res 58:334

Garber JH (1984) Laboratory study of nitrogen and phosphorus remineralization during the decomposition of coastal plankton and seston Estuar Coast Shelf Sci 18:685-702

Goldman JC, Dennett MR (1991) Ammonium regeneration and carbon utilization by marine bacteria grown on mixed substrates. Mar Biol 109:369-378

Golterman HL (1972) The role of phytoplankton in detritus formation. Mem Ist Ital Idrobiol Dolt Marco Marchi 29: $89-103$

Grobben GJ, Chin-Joe I, Kitzen VA, Boels IC, Boer F, Sikkema J, Smith MR, de Bont JAM (1998) Enhancement of exopolysaccharide production by Lactobacillus delbrueckii subsp bulgaricus NCFB 2772 with a simplified defined medium. Appl Environ Microb 64:1333-1337

Grossart HP (in press) Bacterial motility and its implications for the nutrient cycling. Arch Hydrobiol Spec Issues Avd Limnol

Grossart HP, Simon M (1998) Bacterial colonization and microbial decomposition of limnetic organic aggregates (lake snow). Aquat Microb Ecol 15:127-140

Guerrini F, Mazzotti A, Boni L, Pistocchi L (1998) Bacterialalgal interactions in polysaccharide production. Aquat Microb Ecol 15:247-253

Haines KC. Guillard RRL (1974) Growth of vitamin B12 requiring marine diatoms with vitamin B12 producing marine bacteria. J Phycol 10:245-255

Hoppe HG (1993) Use of fluorogenic model substrates for extracellular enzyme activity (EEA) measurements of bacteria. In: Kemp PF, Sherr BF, Sherr EB, Cole JJ (eds) Handbook of methods in aquatic microbial ecology. Lewis Publishers, Boca Raton, p 423-432

Imai I, Ishida Y, Hata $Y$ (1993) Killing of marine phytoplankton by a gliding bacterium Cytophaga sp., isolated from the coastal sea of Japan. Mar Biol 116:527-532

Jürgens $K$, Güde $\mathrm{H}$ (1990) Incorporation and release of phosphorus by planktonic bacteria and phagotrophic flagellates. Mar Ecol Prog Ser 59:271-284 
Kellam SJ, Walker JM (1989) Antibacterial activity from marine microalgae in laboratory culture. Br Phycol J 24:191-194

Kochert G, Olson LW (1970) Endosymbiotic bacteria in Volvox carteri. Trans Am Microsc Soc 89:475-478

Kodama M, Ogata T, Sato T, Sakamoto S (1990) Possible association of marine bacteria with paralytic shellfish toxicity of bivalves. Mar Ecol Prog Ser 61:203-206

Liener IE, Sharon N, Goldstein IJ (1986) The Lectins: Properties, functions and applications in biology and medicine. Academic Press, London

Logan BE, Grossart HP, Simon M (1994) Direct observation of phytoplankton, TEP and aggregates on polycarbonate filters using brightfield microscopy. J Plankton Res 16:1811-1825

Long RA, Azam F (1996) Abundant protein-containing particles in the sea Aquat Microb Ecol 10:213-221

Martinez J, Smith DC, Steward GF, Azam F (1996) Variability in ectohydrolytic enzyme activities of pelagic marine bacteria and its significance for substrate processing in the sea. Aquat Microb Ecol 10:223-230

Mohamed MN, Lawrence JR, Robarts RD (1998) Phosphorus limitation of heterotrophic biofilms from the Fraser River, British Columbia, and the effect of pulp mill effluent. Microb Ecol 36:121-130

Paerl HW, Pinckney JL (1996) A mini-review of microbial consortia: their roles in aquatic production and biogeochemical cycling. Microb Ecol 31:225-247

Porter KG, Feig YS (1980) DAPI for identifying and counting aquatic microflora. Limnol Oceanogr 25:943-948

Pringsheim EG (1912) Die Kultur von Algen in Agar. Beitr Biol Pflanz 11:305-333

Rausch de Traubenberg C, Lassus P (1991) Dinoflagellate toxicity: are marine bacteria involved? Evidence from the literature. Mar Microb Food Webs 5:205-226

Rhee GY (1972) Competition between an alga and an aquatic bacterium for phosphate. Limnol Oceanogr 17:505-514

Rothhaupt KO (1992) Stimulation of phosphorus-limited

Editorial responsibility: Tom Fenchel,

Helsinger, Denmark phytoplankton by bacterivorous flagellates in laboratory experiments. Limnol Oceanogr 37:750-759

Rothhaupt KO, Güde H (1992) The influence of spatial and temporal concentration gradients on phosphate partitioning between different size fractions of plankton: further evidence and possible causes. Limnol Oceanogr 37 : $739-749$

Sastry VMVS, Rao GRK (1994) Antibacterial substances from marine algae: successive extraction using benzene, chloroform and methanol. Bot Mar 37:357-360

Sieburth JMcN (1964) Antibacterial substances produced by marine algae Dev Ind Microbiol 5:124-135

Sieburth JMcN (1968) The influence of algal antibiosis on the ecology of marine microorganisms. In: Droop S, Wood F (eds) Advances in microbiology of the sea. Academic Press, London, p 217-233

Smith DC, Simon M, Alldredge AL, Azam F (1992) Intense hydrolytic activities on marine aggregates and implications for rapid particle dissolution. Nature 359:139-141

Steeman-Nielsen E (1955) The production of antibiotics by planktonic algae and its effect upon bacterial activities in the sea. Deep-Sea Res 3:281-286

Stoderegger K, Herndl GJ (1998) Production and release of bacterial capsular material and its subsequent utilization by marine bacterioplankton. Limnol Oceanogr 43: 877-884

Thingstad T, Skjoldal EF, Bohne RA (1993) Phosphorus cycling and algal-bacterial competition in Sandsfjord, western Norway. Mar Ecol Prog Ser 99:239-259

Wang L, Priscu JC (1994a) Stimulation of aquatic bacterial activity by cyanobacteria. Hydrobiologia 277:145-158

Wang L, Priscu JC (1994b) Influence of phytoplankton on the response of bacterioplankton growth to nutrient enrichment. Freshw Biol 31:183-190

ZoBell CE (1941) Studies on marine bacteria. I. The cultural requirements of heterotrophic aerobes. J Mar Res 4:42-75

Submitted: November 23, 1998; Accepted: February 17, 1999 Proofs received from author(s): August 25, 1999 